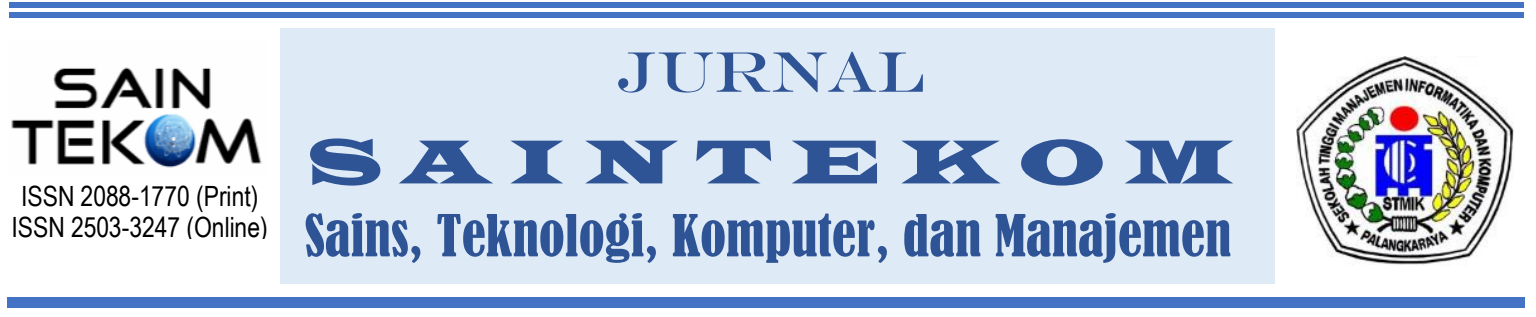

\title{
PERANCANGAN SISTEM INFORMASI KUNJUNGAN PASIEN RAWAT JALAN BERBASIS WEB
}

\author{
*Arijalul Fiqri ${ }^{1}$, Yuda Syahidin ${ }^{2}$, dan Meira Hidayati ${ }^{3}$ \\ 1,2,3) Program Studi Manajemen Informatika Konsentrasi Informatika Rekam \\ Medis, Politeknik Piksi Ganesha \\ Jl. Jenderal Gatot Subroto 301 Bandung \\ Email: afiqri@piksi.ac.id,yuda.syahidin@piksi.ac.id,meira.hidayati@piksi.ac.id
}

\begin{abstract}
The design of an outpatient visit information system is a form of need for the hospital system which is believed to provide convenience for medical record officers in analyzing outpatient visit data. I hope that with the outpatient information system it can be easier to access data and store data. The outpatient visit system is not computerized and officers need to re-enter visit data to manage patient visit data and this is quite time-consuming which causes the information produced to be slow, less accurate and irrelevant. For this reason, researchers evaluate the existing work system at the hospital order to improve good system governance. Researchers use Microsoft Visual Studio 2010 determining the program. The results in this system are that initial introduction to prospective system users, a performance evaluation is carried out to anticipate changes information needs the future and is more thorough in lending and storing medical record files.
\end{abstract}

Keywords : design, information system, visit, outpatient, microsoft visual studio 2010.

\begin{abstract}
ABSTRAK
Perancangan sistem informasi kunjungan pasien rawat jalan merupakan bentuk kebutuhan pada sistem rumah sakit diyakini dapat memberikan kemudahan untuk petugas rekam medis dalam menganalisa data kunjungan pasien rawat jalan. Sehingga diharapkan dengan adanya sistem informasi rawat jalan bisa menjadi lebih mudah untuk mengakses data dan menyimpan data. Pada sistem kunjungan rawat jalan belum sepenuhnya komputerisasi dan petugas perlu memasukkan ulang data kunjungan untuk mengelola data kunjungan pasien dan hal ini cukup menyita waktu yang menyebabkan informasi yang dihasilkan lambat kurang akurat dan tidak relevan. Untuk itu peneliti melakukan evaluasi sistem kerja yang ada pada rumah sakit tersebut agar bisa meningkatkan tata kelola sistem yang baik. Peneliti menggunakan Microsoft Visual Studio 2010 dalam menentukan program. Hasil yang didapat pada sistem ini adalah dilakukan pengenalan awal terhadap calon pengguna sistem dilakukan evaluasi kinerja untuk mengantisipasi perubahan kebutuhan informasi di masa mendatang dan Lebih teliti dalam meminjamkan dan menyimpan berkas rekam medis.
\end{abstract}


Kata kunci : perancangan, sistem informasi, kunjungan, rawat jalan, microsoft visual studio 2010.

\section{PENDAHULUAN}

Sistem informasi kunjungan pasien rawat jalan merupakan salah satu penunjang pengguna untuk memberikan hasil yang lebih baik pada output sebuah sistem hal ini dapat diperhitungkan dalam dunia kesehatan maupun rumah sakit karena pelayanan kesehatan bergantung pada sistem informasi yang di dapat dan digunakan sebagai cara untuk memberikan pelayanan terhadap pasien.

Penerapan sistem komputerisasi adalah salah satu karya nyata yang sudah dihasilkan oleh manusia. Dengan sistem komputerisasi ini diharapkan mampu menyelesaikan pekerjaan dengan cepat dan tepat serta mampu meminimalisir kesalahan yang dapat terjadi. Pelayanan pasien untuk observasi, diagnosis, pengobatan, rehabilitasi medik dan pelayanan kesehatan lainnya harus tanpa menginap di rumah sakit menurut Permenkes (KEPUTUSAN MENTERI KESEHATAN INDONESIA REPUBLIK 560/MENKES/SK/IV/2003). Rekam Medis merupakan berkas yang berisi dokumen dan catatan pasien antara lain identitas pasien hasil pemeriksaan pengobatan yang telah diberikan serta tindakan dan pelayanan lainnya yang telah diberikan kepada pasien (PERMENKES REPUBLIK INDONESIA NOMOR 269/MENKES/PER/III/2008). Hasil informasi tersebut dapat dijadikan bahan untuk melakukan perencanaan pengadaan sarana dan prasana kesehatan serta sumber daya manusia di fasilitas pelayanan kesehatan.

Penerimaan pasien rawat jalan biasa disebut sebagai TPPRJ (Tempat Penerimaan Pasien Rawat Jalan). Tujuan utamanya adalah untuk menerima pasien berobat ke poliklinik yang dituju, oleh masing-masing pasien tersebut menurut (dirjen Yanmed 2006). Di rumah sakit $\mathrm{x}$ memerlukan pengelolaan secara efektif dan efisien termasuk dalam pengelolaan data pasien rawat jalan. Kualitas sistem informasi adalah keseluruhan ciri suatu produk atau jasa yang menunjukkan kemampuan untuk memenuhi kebutuhan konsumen. Bentuk permintaan adalah permintaan yang mengklaim mampu memenuhi permintaan implisit (Efendi 2009). 
Kualitas pelayanan merupakan salah satu indikator untuk mengukur kualitas pelayanan kesehatan. Menentukan citra organisasi pelayanan kesehatan di benak masyarakat. Mutu pelayanan ditingkatkan berdasarkan pada standar pelayanan, standar profesi, sesuai kebutuhan pasien, menggunakan teknologi yang tepat guna menghasilkan hasil penelitian yang baik serta dengan perkembangan pelayanan kesehatan dan keperawatan telah tercapai tingkat pelayanan yang efisien dan efektif. Berdasarkan hasil yang diperoleh dapat kita ambil perspektif atau sudut pandang bahwa mutu pelayanan kesehatan adalah kesesuaian pelayanan kesehatan dengan standar profesi yang memanfaatkan sumber daya dengan ada secara baik sehingga semua kebutuhan pelanggan dan tujuan untuk mencapai harkat kesehatan yang efektif dan dapat tecapai. Pelayanan kesehatan baik di rumah sakit atau di fasyankes lainnya merupakan suatu sistem yang terdiri dari berbabagi komponen yang saling terkait, saling tergantung, dan saling mempengaruhi antara satu dengan yang lainnya. Pelayanan mutu kesehatan di rumah sakit merupakan bentuk akhir dari hubungan dan ketergantungan yang erat antara komponen atau aspek pelayanan.

Penelitian terdahulu dilakukan oleh Warijan, Elise Garmelia, Sri Lestari, dan Endah Dwi Lestari pada tahun 2018 dengan mengambil judul prediksi kunjungan pasien rawat jalan tahun 2018-2022(Warijan et al. 2018).

Permasalahan yang dibahas dalam penelitian ini adalah ingin mengetahui prediksi kunjungan pasien rawat jalan tahun 2018-2022 di RSUD RAA Soewondo Pati yang merupakan rumah sakit rujukan dengan kunjungan pasien setiap tahunnya meningkat. Keberadaan suatu sistem informasi yang akurat dan andal, serta cukup untuk meningkatkan pelayanan kepada pasien dan lingkungan terkait lainnya. Kunjungan merupakan kepercayaan pasien terhadap organisasi penyelenggara pelayanan kesehatan dapat memenuhi kebutuhannya. meningkatnya kunjungan pasien ke fasilitas pelayanan kesehatan dapat dilihat pada waktu tertentu, yaitu harian, mingguan, bulanan dan tahunan.

Kunjungan pasien pada Instalasi Rawat Jalan merupakan salah satu aktifitas yang biasa kita lihat hampir di setiap hari di rumah sakit dan pusat pelayanan kesehatan lainnya, baik 
sebagai kunjungan lama maupun kunjungan baru. naik turunnya jumlah kunjungan pasien di Instalasi Rawat Jalan memeperlihatkan perubahan kebutuhan ataupun keinginan masyarakat dalam pengobatan, serta menunjukkan perubahan kedalaman penyakit yang sering terjadi di masyarakat. Dengan adanya sistem informasi kunjungan rawat jalan akan memudahkan petugas rekam medis untuk menganalisa data kunjungan pasien rawat jalan. Sehingga diharapkan dengan adanya sistem informasi rawat jalan bisa menjadi lebih mudah untuk mengakses data dan menyimpan data.

\section{METODE}

Penelitian ini menggunakan rancangan atau desain penelitian deskriptif analisis. suatu metode yang berfungsi untuk menjelaskan gambaran terhadap objek yang diteliti melalui data atau sampel yang telah terkumpul sebagaimana adanya (Sugiyono 2009). Berikut penjelasan metode diatas dapat dilihat pada gambar 1 tentang metode waterfall.

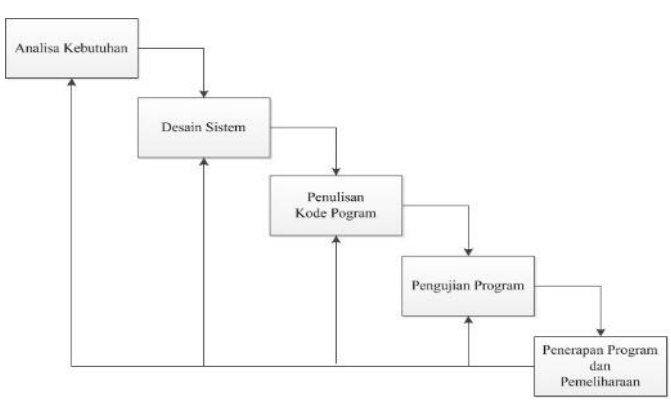

Gambar 1. Ilustrasi Model Waterfall

\subsection{Analisis Kebutuhan}

Pada tahap analisa mengenali permasalahan yang terjadi pada kebutuhan sistem dan mengenali permasalahan yang terjadi pada komponen tersebut. Dalam kesempatan ini penulisan melakukan analisa terhadap kebutuhan dalam membuat sistem perancangan dengan menggunakan aplikasi berbasis web yaitu Microsoft Visual Studio 2010.

\subsection{Desain}

Pada tahap desain penyaluran gagasan dan pemikiran penulis akan dilakukan dalam bentuk perancangan sistem dengan permasalahan yang terjadi menggunakan model Entity Relationship Diagram (ERD)

\subsection{Pengkodean}

Pada tahap pemograman penulis melakukan implementasi sistem rancangan dengan nyata yang saling berhubungan dengan pemilihan perangkat keras dan menyusun perangkat lunak aplikasi. 


\subsection{Pengujian Program dan Implementasi}

Pada tahap ini penulis melakukan perancangan perangkat lunak dan dapat dilakukan sebagai rangkaian program. Dilakukan juga pengujian terhadap sistem web.

\subsection{Penerapan Program dan Maintenance}

Pada tahap ini penerapan sistem program harus selalu di periksa dan di upadate supaya program tetap berjalan baik tidak ada kendala dan sesuai dengan harapan yang diinginkan.

\subsection{Analisis Sistem Yang Berjalan Saat Ini}

Setelah melakukan analisis sistem informasi, penelitian ini melakukan perencanaan untuk mengetahui seluruh permasalahan yang terjadi terhadap sistem yang sedang berjalan, penelitian ini menemukan berbagai permasalahan yang terjadi pada sistem informasi kunjungan rawat jalan. sehingga memudahkan dalam menjalankan tahap selanjutnya yaitu tahap perancangan sistem yang berguna untuk memberikan pemecahan solusi. Analsis sistem adalah merupakan sebuah teknik memberikan pemecahan masalah yang menjelaskan sebuah sistem menjadi komponen- komponennya dengan tujuan untuk mempelajari seberapa bagus komponenkomponen tersebut bekerja dan berinteraksi untuk meraih tujuan yang telah ditentukan (Mulyanto 2019). Permasalahan yang terjadi pada sistem informasi ini adalah :

a. Ada data kunjungan yang tidak dilakukan, seperti: data kunjungan per hari dan data kunjungan per jenis pasien, sehingga tidak adanya spesifikasi di dalam data kunjungan tersebut.

b. Proses pengolahan data kunjungan rawat jalan masih dilakukan secara input manual data ke Microsoft Excel, dan membutuhkan waktu yang cukup lama dalam menggolah data sehingga informasi yang di dapat kurang akurat dan tidak relevan.

c. Beberapa pasien ditemukan tidak membawa Kartu Identitas Berobat (KIB) sehingga membuat pengerjaan menjadi kurang efektif karena harus mencari dulu data yang bersangkutan dengan data pasien tersebut.

d. Adanya beberapa berkas rekam medis yang tidak di temukan sehingga petugas harus menyiapkan data baru atau data sementara untuk 
pasien yang tidak ada berkas rekam medis nya.

Berikut penjelasan sistem yang berjalan pada saat ini dijelaskan oleh gambar 2.

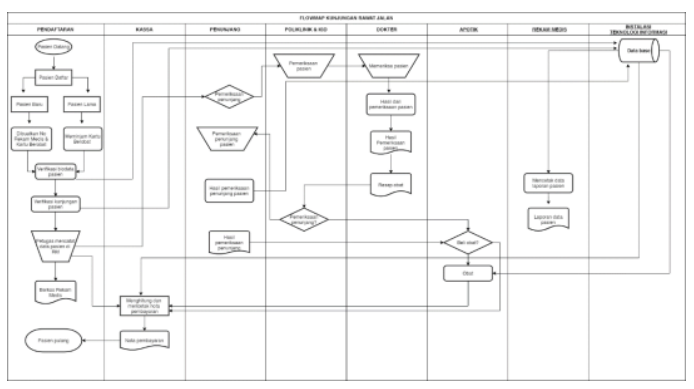

Gambar 2. Flowchart Yang Berjalan Saat Ini

\subsection{Solusi Pemecahan Masalah}

Salah satu upaya yang dapat dilakukan adalah tahap analisa, tahap ini di lakukan untuk menjelaskan atau mendefenisikan permasalahan yang timbul yang ada pada sistem informasi tersebut. Hal ini diperlukan untuk memperbaiki atau memberikan masukan perbaikan ke depannya supaya tidak ada kesalahan pada sistem informasi tersebut cara untuk mengatasi masalah tersebut yaitu diantaranya :

a. Petugas pendaftaran menyiapkan buku kecil yang berisi kode indeks dan alat-alat tulis yang dibutuhkan untuk input data pasien sebelum jam kerja dimulai, setelah selesai jam kerja petugas melakukan input data ulang ke Microsoft Excel supaya mempercepat penginputan di rumah sakit.

b. Petugas rekam medis telah menyimpan berkas rekam medis pasien kedalam rak penyimpanan yang sudah di siapkan oleh rumah sakit tersebut.

c. Petugas mengingatkan pentingnya membawa Kartu Identitas Berobat (KIB) kepada pasien supaya pasien lebih teliti dan memahami penting Kartu Identitas Berobat untuk identitas pasien.

d. Petugas lebih teliti dalam memastikan peminjaman dan pengembalian rekam medis supaya tidak hilang atau tercecer di poliklinik mudah di temukan.

Pada Pemecahan masalah ini dapat dijabarkan melalui flowchart pada gambar 3 dibawah ini.

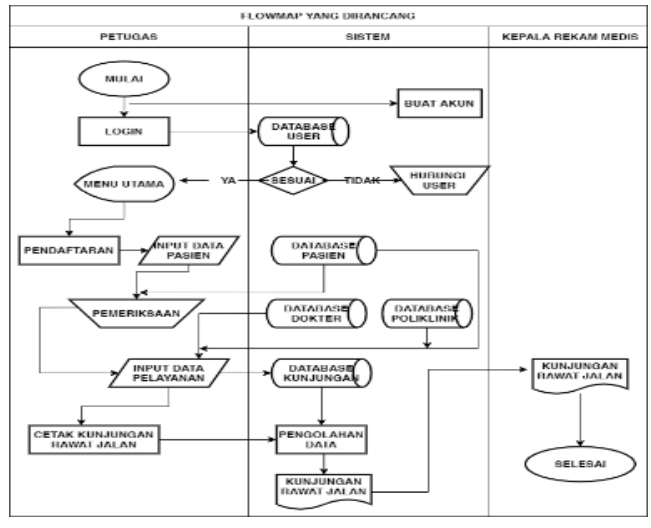

Gambar 3. Flowchart Yang Direncanakan 


\section{HASIL DAN PEMBAHASAN}

\subsection{Analisis Kebutuhan Sistem}

Berdasarkan permasalahan yang telah dibahas sebelumnya, pada analisis kebutuhan sistem ini merupakan proses penguraian sistem menjadi beberapa sub sistem yang lebih kecil, dengan tujuan untuk mempermudah dalam mengidentifikasi masalah, hambatan, dan peluang yang ada pada sistem. Dengan cara ini, metode yang lebih baik dapat diusulkan untuk sistem. Tahapan ini merupakan salah satu tahapan yang penting, karena kesalahan dalam mengidentifikasi masalah pada sistem dapat menimbulkan kesalahpahaman pada saat merancang sistem. Hal ini dapat menyebabkan desain yang tidak valid. Berikut penjelasan pada gambar 4 yang menjelaskan Data Flow Diagram pada sistem tersebut.

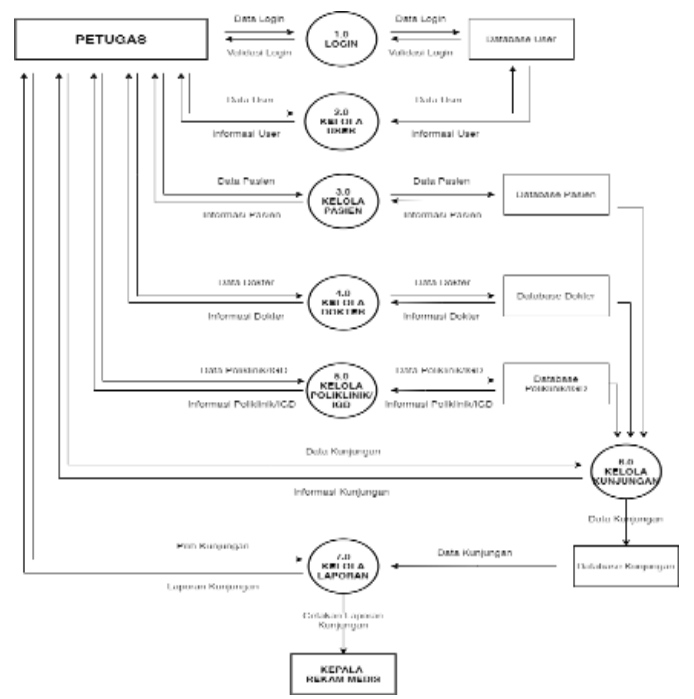

Gambar 4. Data Flow Diagram

\subsection{Perancangan Activity Diagram}

Activity Diagram merupakan gambaran sebuah proses alur dan urutan aktivitas dalam sebuah proses, yang biasanya digunakan untuk memperlihatkan urutan aktivitas alur kerja suatu sistem. Activity diagram juga dapat digunakan menggambarkan logical procedural system, dan aliran kerja kasus lainnya. Pembuatan activity ini memiliki fungsi untuk membantu proses secara keseluruhan.

\subsubsection{Activity Diagram Login}

Diagram activity login menggambarkan urutan activity para pengguna dapat masuk ke sistem setelah berinteraksi dengan sistem. Aktivitas dimulai dengan pengisian username pengguna dan password seperti yang dijelaskan pada aktivitas gambar 5 di bawah ini.

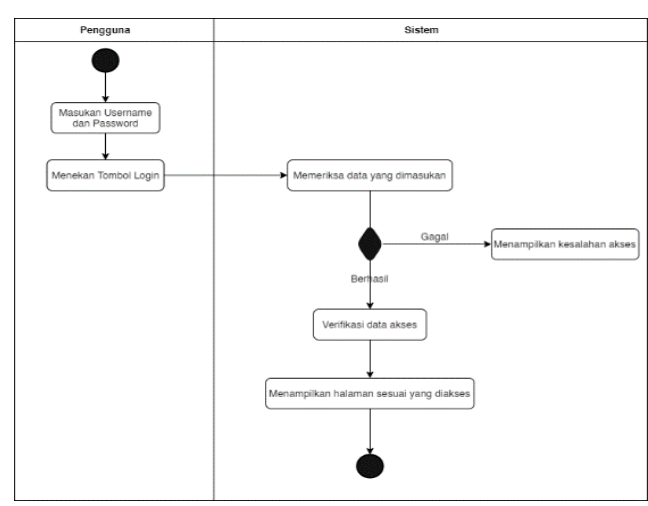

Gambar 5. Activity Diagram Login 
3.2.2 Activity Halaman Diagram

\section{Login}

Activity

halaman profil

mendeskripsikan aktivitas yang

dilakukan oleh petugas untuk

melakukan laporan pada sistem

informasi.

\subsubsection{Basis Data}

Basis data merupakan kumpulan informasi yang disimpan melalui komputer secara beraturan sehingga dapat diperiksa menggunakan suatu program komputer yang mendapatkan informasi dari basis data tersebut. Tahap yang digunakan merancang basis data (database) dengan menggunakan model Entity Relationship Diagram (ERD), dan

kemudian di jabarkan dengan relasi tabel.

\section{a. Entity Relationship Diagram}

Salah satu model yang mengimplementasikan hubungan antar data dalam basis data dengan menggunakan objek-objek dasar data yang memiliki hubungan dengan antar relasi lainnya.

Dijelaskan pada gambar 6 tentang Entity Relationship Diagram yang memodelkan struktur data dan hubungan antar data, untuk beberapa notasi dan simbol.

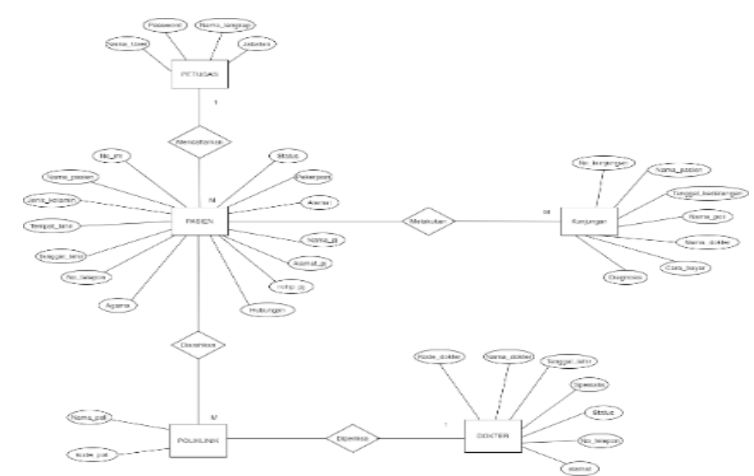

Gambar 6. Entity Relationship Diagram

\section{b. Relasi Antar Tabel}

Relasi merupakan sebuah hubungan yang terjadi pada suatu tabel dengan lainnya yang menjelaskan hubungan antar objek yang nyata dan berfungsi untuk mengatur dan mengarahkan operasi suatu database. Berikut gambar 7 yang menjelaskan relasi antar tabel pada sistem tersebut.

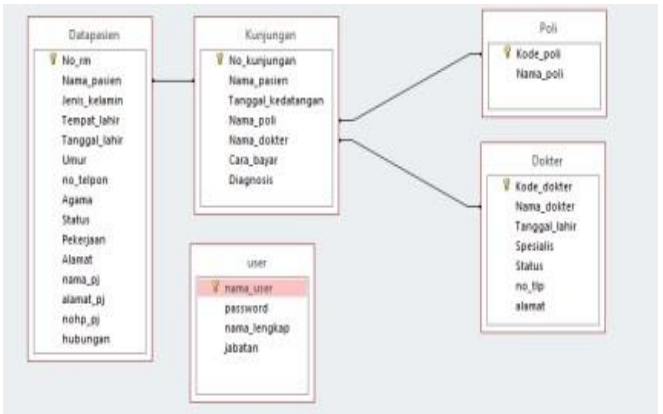

Gambar 7. Relasi Antar Tabel

\subsection{Rancangan Antarmuka Interface}

Antar muka pengguna interface adalah aktivitas untuk menggambarkan suatu tampilan yang sudah di desain sebelumnya. Antar muka dari sistem informasi pasien kunjungan rawat jalan yaitu terdiri dari beberapa bagian pengelola aplikasi diantara nya dijelaskan pada gambar dibawah ini : 


\section{a. Halaman Login}

Dalam halaman login terdapat username dan password jika ingin masuk pada menu sistem kita harus melakukan pengisian pada button teks tersebut lalu klik tombol login yang di jelaskan pada gambar 8 .

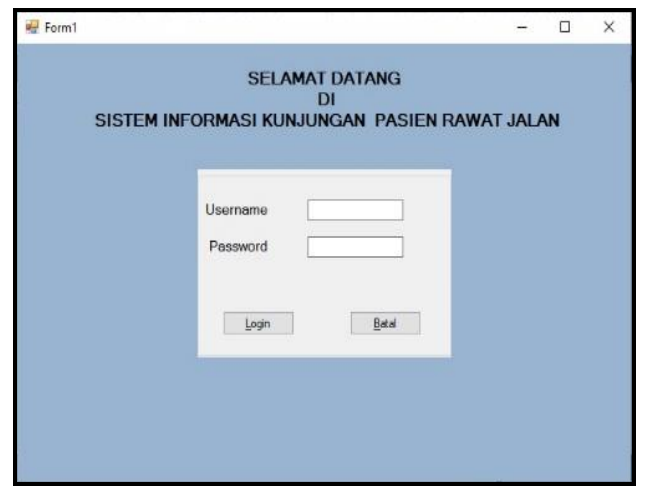

Gambar 8. Halaman Login

\section{b. Halaman Menu}

Pada halaman menu terdapat button pilihan yaitu file, master data, kunjungan pasien dan laporan pilih sesuai kebutuhan terdapat pada gambar 9.

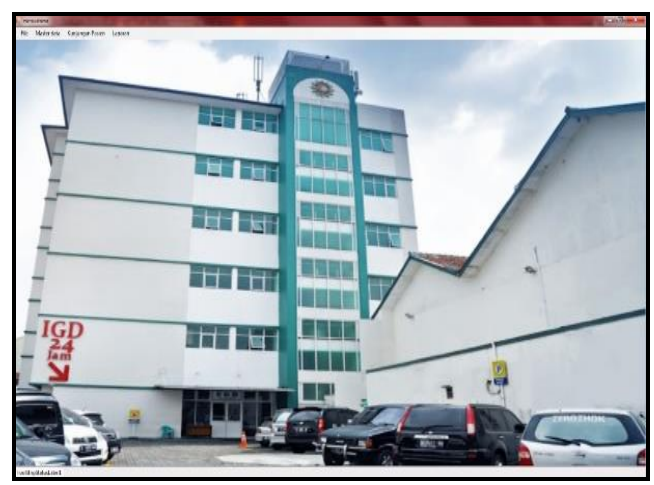

Gambar 9. Halaman Menu

\section{c. Halaman Kunjungan Pasien}

Halaman kunjungan pasien berguna untuk memeriksa jumlah kunjungan pasien yang tertera pada tanggal, bulan, dan tahun lalu klik tombol cetak jika ingin melihat jumlah kunjungan dalam bentuk tabel pada gambar 10 .

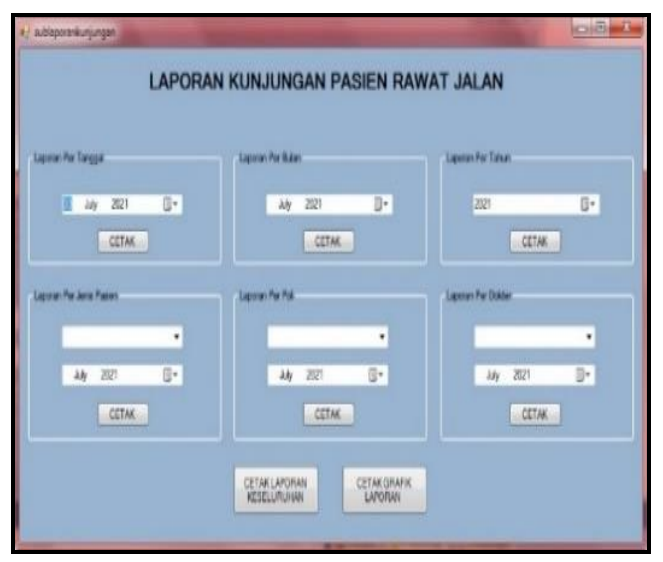

Gambar 10. Halaman Kunjungan Pasien

\section{d. Halaman Kelola Laporan}

Pada gambar 11 dijelaskan halaman kelola laporan digunakan untuk mengubah, menambahkan, dan menghapus data pasien kunjungan.

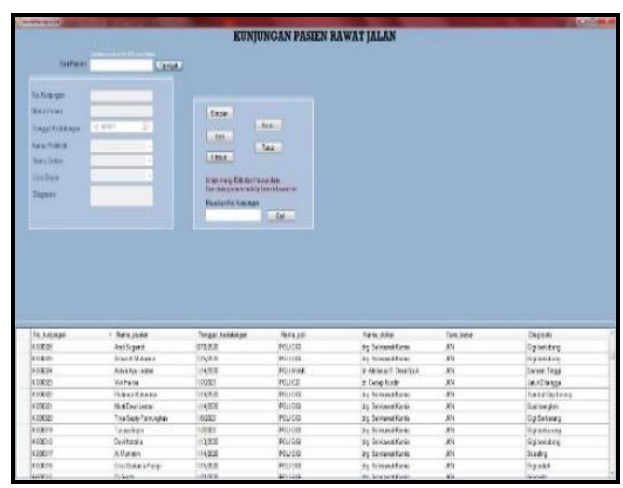

Gambar 11. Halaman Laporan

\section{e. Hasil Laporan}

Pada hasil laporan dijelaskan jumlah data kunjungan pasien yang ada pada rumah sakit seperti pada gambar 12. 


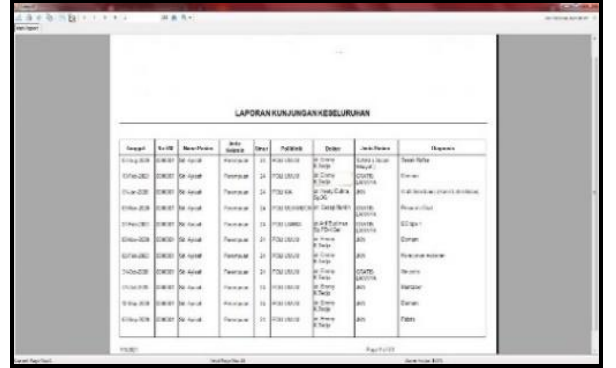

Gambar 12. Laporan Keseluruhan

\section{SIMPULAN}

Dari hasil perancangan sistem informasi kunjungan pasien rawat jalan dapat disimpulkan bahwa pentingnya pengolahan data kunjungan pasien dilakukan dengan basis web agar selalu bisa update data supaya memudahkan petugas rekam medis untuk melakukan laporan kunjungan, menganalisis data kunjungan, dan mengatur data kunjungan rumah sakit.

Adanya pengembangan sistem informasi kunjungan rawat jalan diharapkan dapat memberikan perubahan, serta dapat dijadikan sebagai salah satu solusi atau upaya pemecahan masalah terhadap sistem yang berjalan, sehingga proses pengolahan kunjungan rawat jalan bisa dilakukan secara komputerisasi sepenuhnya.

Perlu dilakukan sosialisai terhadap pasien bahwa Kartu Identitas Berobat itu sangatlah penting.

Perlu dilakukan analisis kinerja sistem baru secara berkala, hal ini dilakukan selain untuk analisis sistem juga untuk mengantisipasi perubahan kebutuhan sistem informasi di masa mendatang.

Pada sistem kunjungan pasien rawat jalan kita dapat mengidentifikasi jumlah pasien yang datang ke rumah sakit, jumlah penyakit yang sama dan mengetahui data pasien yang belum ada pada sistem informasi tersebut.

\section{DAFTAR PUSTAKA}

Dirjen Yanmed. 2006. Penerimaan Pasien Rawat Jalan Dinamakan TPPRJ (Tempat Penerimaan Pasien Rawat Jalan).

Efendi, Ferry \& Makhfud. 2009. Keperawatan Kesehatan Komunitas Teori Dan Praktik Dalam Keperawatan. Jakarta: Salemba Medika.

INDONESIA, PERATURAN MENTERI KESEHATAN

REPUBLIK, and NOMOR 269/MENKES/PER/III/2008. 2008.

Tentang Rekam Medis. Jakarta. KEPUTUSAN

MENTERI

KESEHATAN

INDONESIA

REPUBLIK NOMOR 560/MENKES/SK/IV/2003. 2003. Pola Tarif Perjan Rumah Sakit Menteri Kesehatan Republik Indonesia.

Mulyanto, Aunur R. 2019. 53 Journal of

Chemical Information and Modeling Rekayasa Perangkat Untuk Sekolah Menengah Kejuruan.

Sugiyono. 2009. Metode Penelitian Kuantitatif, Kualitatif Dan $R \& D$. Bandung: Alfabeta.

Warijan, Elise Garmelia, Sri Lestari, 
and Endah Dwi Lestari. 2018.

"Prediction of Visits of Outpatients in 2018-2022 Prediksi Kunjungan Pasien Rawat Jalan Tahun 20182022 Poltekkes Kemenkes Semaran , 4 ) RS Kartika Husada Kudus J1 . Tirto Agung , Pedalangan , Banyumanik , Semarang." Jurnal Rekam Medis dan Informasi Kesehatan 1(Oktober): 89-96. 